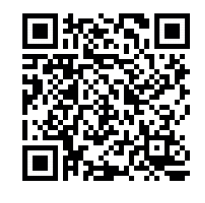

Keywords:

Vegetative propagation Periodicity in rooting Rooting speed Logistic model

Historic:

Received 09/10/2018 Accepted 12/12/2018

Correspondence: marcio.navroski@udesc.br
Mariane de Oliveira Pereira', Alessandro Camargo Ângelo', Marcio Carlos Navroski ${ }^{2+}$, Marcos Felipe Nicoletti ${ }^{2}$, Bruno Nascimento ${ }^{2}$, Alexandra Cristina Schatz Sá2, Ezequiel Gasparin $^{3}$, Queli Cristina Lovatel ${ }^{2}$

\section{ROOTS OF MINI-CUTTING OF CLONES OF SEQUOIA SEMPERVIRENS IN DIFFERENT SEASONS OF THE YEAR}

PEREIRA, M. O.; ÂNGELO, A. C.; NAVROSKI, M. C.; NICOLETTI, M. F; NASCIMENTO, B., SÁ, A. C. S; GASPARIN, E., LOVATEL, Q. C. Roots of mini-cutting of clones of Sequoia sempervirens in different seasons of the year. CERNE, v. 24, n. 4, p. 452-460, 2018.

\section{HIGHLIGHTS}

The rooting process of sequoia minicuttings presents clonal influence.

The average rooting is over $85 \%$ in all seasons.

The rooting of minicuttings occurs between 50 and 70 days.

It is indicated the presence of 90 days of minicuttings in the rooting environment.

\section{ABSTRACT}

We analyzed the rooting of sequoia mini-cuttings from different clones in the four seasons of the year and the use of the logistic model to estimate the time of maximization of rooting in each factor of analysis. Mini-cuttings of five clones grown in clonal mini-garden were placed to root in mini-tunnel in four seasons of the year. Weekly evaluations were performed (from 30 to 93 days) of these variables: survival (\%), rooted mini-cuttings (\%) and a number of emitted roots. These data were used to adjust the original logistic function. The experiment was set in completely randomized design, in a factorial scheme of 5 (clones) $\times 4$ (seasons), using five replicates of 50 mini-cuttings per experimental unit. During the winter the lowest rooting of mini-cuttings was achieved $(85 \%)$, with rates higher than $90 \%$ in other seasons. In winter, slower rooting also occurred, around 60 70 days, while in other seasons it was between 50-60 days after mini-cutting planting. The rooting process is dependent on the clones. Our data showed that four clones presented rooting greater than $90 \%$ and one less than $70 \%$. In general, mini-cuttings can be performed at any time of the year, recommending the period of 90 days in mini-tunnel.
' Federal University of Paraná, Curitiba, Paraná, Brazil - ORCID:

2 University of the State of Santa Catarina, Lages, Santa Catarina, Brazil - ORCID:

${ }^{3}$ Federal University of Santa Maria, Santa Maria, Rio Grande do Sul, Brazil - ORCID 


\section{INTRODUCTION}

Sequoia sempervirens (sequoia) is endemic to the coastal area from southwest Oregon to California (USA). In the natural environment this species grows on podzols or clay soils and generally between 30 and $750 \mathrm{~m}$ above sea level, reaching up to $950 \mathrm{~m}$, requiring high humidity and abundant rainfall. The species shows a good initial growth when compared to other conifers (Donnet, 1984). With the exception of New Zealand and Chile, where small-scale plantations occur, in other countries the species was used only for landscaping purposes, including Brazil. This restriction is mainly due to the difficulty of seed germination, which is considered low $(<10 \%)$ due to the large production of empty seeds and predation by parasites (Bourgkard and Favre, 1989).

In natural areas, the sequoia can also reproduce spontaneously from basal shoots, showing a potential of seedlings production by vegetative propagation. Vegetative propagation is useful in the production of seedlings in species which show difficulty to propagate by seeds. Furthermore it is an important tool in a genetic improvement program. The establishment of clonal forestry selected through vegetative propagation increases production, maintains the uniformity of the improved material, and enables multiplication of individuals resistant to pests and diseases and adapted to specific sites, among other advantages. Thus, it is an important tool to propagate tree species (Tosta et al., 2012).

Several factors can affect the success of clonal propagation by mini-cuttings technique, such as juvenile period, the season of propagules collection, application of plant growth regulators, carbohydrates, nutrition, water relations, temperature, air humidity and factors related to genetics, such as provenances or clones (Brondani et al., 2018). Another factor that has direct influence and may limit the processes of rooting is the seasonality (Trueman et al., 20l3), mainly in subtropical environments such as in southern Brazil. The season of the year can determine the rooting of mini-cuttings by affecting the physiological conditions, the stage of growth, hormonal balance and lignification degree of the propagule (Tombesi et al., 20l5). Environmental conditions may change through sensitivity or variation in the level of endogenous auxins. These seasonal variations in auxin levels can be correlated to rooting capacity, but the effect is species-specific (Ling and Zhong, 2012).

Therefore, knowing the seasons more favorable to rooting in different periods of the year, management strategies aiming at optimizing the plant production of previously selected genotypes can be adopted. In this sense, mathematical models, such as logistic model, can assist in the determination of the time of maximum rooting and in the appropriate period for the removal of mini-cuttings from the propagation environment. Some studies with eucalyptus were carried out successfully using mathematical models (Oliveira et al., 20I2).

Thus, it is hypothesized that sequoia trees have better rooting in the seasons with higher temperature, as it happens for the majority of the arboreal species planted in tropical or subtropical areas (Alcantara et al., 2008), and that the clones demonstrate differences in behavior for roots emission. In this way, this paper aims at evaluating the rooting of sequoia mini-cuttings of different clones in four seasons of the year and the use of logistic model to estimate the time of rooting maximization in each factor of analysis.

\section{MATERIAL AND METHODS}

Propagule sources used in the experiment were select from sequoia matrices (located in São Francisco de Paula, Rio Grande do Sul state, Brazil) with approximately 40 years of age, propagated by the conventional cutting technique. After 120 days, propagules were collected from the parent plant obtained by total girdling or partial girdling. The material was transported in styrofoam boxes with ice (transport lasted approximately 4 hours) to the Forest Nursery located in Lages, Santa Catarina state, Brazil. After that, cuttings with a size of $10 \mathrm{~cm}$ containing a pair of acicular leaves were reduced to $50 \%$ of the leaf area and were treated with $6,000 \mathrm{mg} \cdot \mathrm{L}^{-1}$ of indole-3-butyric acid (IBA). Then, the cuttings were placed in tubes $\left(180 \mathrm{~cm}^{-3}\right)$ containing vermiculite and commercial substrate (peat, vermiculite, pine bark and charcoal) and kept in a mini-tunnel for rooting.

Five-month-old rooted cuttings were acclimatized in a shade house (covered with nylon screen with 30 $35 \%$ shade and with an average temperature of $23^{\circ} \mathrm{C}$ ) during 30 days; the cuttings were then transferred to the greenhouse (covered with low-density polyethylene and with an average temperature of $28^{\circ} \mathrm{C}$ ) to complete the acclimatization for more 30 days. Subsequently, plants with approximately $20 \mathrm{~cm}$ of height were transferred to pots with $5 \mathrm{~L}$ capacity, filled with commercial substrate (50\%) (the same type used in cutting) and vermiculite of medium granulometry (50\%). Fifteen days after the installation of the experiment, the time for the plants to adapt to the system, the apex of the main bud was pruned at $10 \mathrm{~cm}( \pm 2 \mathrm{~cm})$ of height for forming the ministumps for the establishment of the clonal mini-garden. Monthly, during a period of four months, pruning of the mini-stumps was carried out. 
Nutrient solution used in the clonal mini-garden was provided by commercial fertilizer $\left(\right.$ Forth $\left.^{\circledR}\right)$ composed of $10 \% \mathrm{~N} ; 42 \% \mathrm{P}_{2} \mathrm{O}_{5}$ (water soluble); $10 \% \mathrm{~K}_{2} \mathrm{O}$ (water soluble); $0.6 \% \mathrm{Mg} ; 0.1 \% \mathrm{Fe}$ and $0.02 \mathrm{Br}$. Fertigation was done twice a week, with each mini-stump receiving $50 \mathrm{ml}$ of solution composed by 1.5 grams of the fertilizer per liter of water. After the period of mini-stumps formation, the sprouts were collected to perform the experiments.

Five clones from the clonal mini-garden, called AI27, AI33, AI 40, A227 and A228, were used. From the shoots obtained from these clones, mini-cuttings with 8 to $10 \mathrm{~cm}$ in length with a pair of acicular leaves reduced to $50 \%$ of the leaf area were prepared. The mini-cuttings were placed in $180 \mathrm{~cm}^{3}$ polypropylene tubes, containing the blend of two commercial substrates $(I: I \mathrm{v} / \mathrm{v})$, with the base of the mini-cutting inserted approximately $2 \mathrm{~cm}$ in the substrate, without using plant growth regulators. According to the manufacturer's information, the first substrate is composed of peat, expanded vermiculite, pine bark, and charcoal. The second commercial substrate is composed of pine bark, charcoal, carbonized rice husk, coconut fiber, vermiculite, calcareous $(0.2 \%)$ and triple superphosphate $(0.1 \%)$. The chemical and physical characteristics of the mixture, according to the substrate analysis, are the following: $\mathrm{pH}=6.3$; electrical conductivity $=0.24 \mathrm{mS} \cdot \mathrm{cm}^{-1}$; wet density $=579.3 \mathrm{~kg} \cdot \mathrm{m}^{-3} ;$ dry density $=$ $307.5 \mathrm{~kg} \cdot \mathrm{m}^{-3}$; current humidity $=46.9(\%)$; total porosity $=84.5(\%)$; aeration space $=32.9(\%)$; easily available water $=13.2(\%)$; buffer water $=2.1(\%)$; remainder water $=36.3(\%)$; CRAIO - water holding capacity at 10 $\mathrm{cm}=51.6 ;$ CRA $50=38.4$; and CRAI00 $=36.3$.

After the mini-cuttings were inserted in rooting media, the trays containing the tubes were conditioned in a rooting environment (mini-tunnel). The mini-tunnel is a structure with plastic cover, with $8.0 \times 1.20 \times 0.9 \mathrm{~m}$ (length $\times$ width $\times$ height), located under the shade house. Irrigation was performed by a micro sprinkler system with five daily irrigations of 7 minutes (09:00 a.m.; II:30 a.m.; 0I:30 p.m.; 3:30 p.m.; 6:00 p.m.). Data of humidity and temperature means were obtained from a datalogger every 10 minutes. The average monthly values of temperature and humidity of the experiment period (Sep/2016 until Aug/2017) are shown in Figure I.

The experiment was set in a completely randomized design, in a $5 \times 4$ factorial scheme (five clones $x$ four seasons), using five replicates of 50 mini-cutting per experimental unit (five mini-cutting per repetition at each evaluation). Weekly evaluations were carried out ( 10 weeks), starting from the $30^{\text {th }}$ day after mini-cutting planting, until the $93^{\text {rd }}$ day, when there was stabilization of rooting for most of the clones in the different seasons. The mini-cuttings evaluated in one period were no longer used in the next evaluations to avoid interference with the withdrawal and replacement of the same ones.

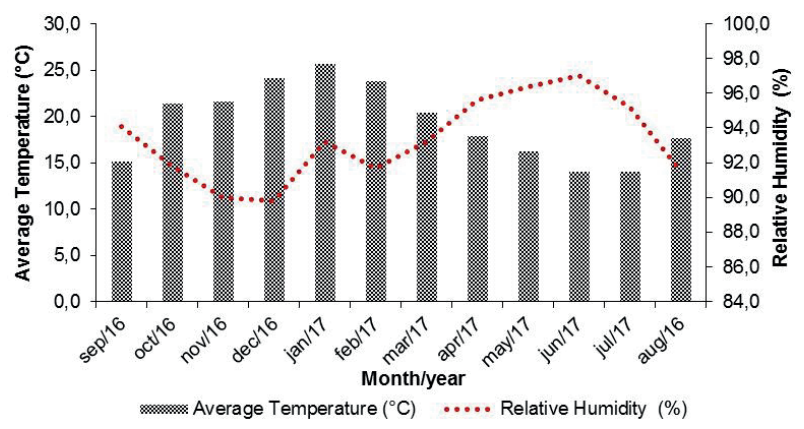

FIGURE I Monthly means (Sep/20I6 until Aug/20I7) of average temperature $\left({ }^{\circ} \mathrm{C}\right)$ and relative humidity of air (\%) in mini-tunnels used for the conditioning of minicuttings of Sequoia sempervirens.

The survival of mini-cuttings (\%), callus formation (\%), rooting (\%) and the number of roots emitted was evaluated. Survivors were considered mini-cuttings that had live tissue, old leaves or young shoots, rooted or not. The percentage of rooted was considered on the total, not only on the surviving. Rooted mini-cuttings were those with a root primordial greater than $2 \mathrm{~mm}$. Data were submitted to normality by KolmogorovSmirnov test and homogeneity by Bartlett test. The data of final evaluation ( 93 days) were subjected to analysis of variance and when there was a significant difference by $F$ test the means were compared by the Scott-Knott test at $5 \%$ probability. The logistic function was used to describe variations of the dependent variable (in the case of this study, survival, callus formation, rooting and a number of roots) as a function of time. The equation obtained for each clone and season was expressed by the coefficient $\varphi_{2}$ for maximum rooting potential. The logistic function was represented by the following equation, where $V i$ $=$ variable observed in the $i_{\text {th }}$ mini-cutting; $T i=$ time in the $i_{\text {th }}$ mini-cutting depending on the days after planting; $\varphi_{i}=$ regression coefficients and $e_{i}=$ random error. Data analysis were carried out using $\mathrm{R}$ software.

$V i=A_{4}+\frac{A_{2}-A_{4}}{1+\exp \left[\left(A_{3}-T i\right) / A_{4}\right]}+e_{i}$

\section{RESULTS}

There was no significant differences in percentage of survival and callus formation in the sequoia tree mini-cuttings evaluated in different periods, and either no adjustment of the original logistic function. The mean survival was $98.5 \%$ and the callus $76.5 \%$, considering weekly evaluations from 30 to 93 days. In relation to rooting, based on the shape of the curve and the estimates parameters $\varphi$, it was possible to verify that there was a significant difference in the rooting percentage in the different seasons of the year for the five clones 
tested (Figure 2). In the spring, the rooting began around 40 days after mini-cutting. Clone Al40 was the first to show rooting ( $25 \%$ in the evaluation at 37 days). This same clone had already obtained $100 \%$ of rooting near the 70 days, maintaining this mean until the final evaluation. For the other clones, the period of greatest rooting occurred between 60 and 80 days. With the exception of clone AI33, which obtained maximum rooting near $70 \%\left(\varphi_{2}=\right.$ 7I.386), the others obtained practically 100\%.

In the sequoia mini-cutting performed in the summer, rooting also started close to 40 days (Figure $2 \mathrm{~b}$ ). There were similarities in the rooting process in three clones between 30 and 70 days after planted. After 70 days, these three clones diverge in the rhizogenic process, varying between $78 \%$ (AI33) and 100\% (A227). For clone AI27 rooting maximization ( $290 \%$ ) occurred close to 65 days, maintaining this behavior until the end of the evaluation. Just like in the spring, clone AI40 showed the highest precocity in root formation, reaching almost $100 \%$ rooting at 60 days. The spring-like response was also observed in clone AI33, with the lowest rooting (close to $70 \%$ ).

The rooting of mini-cuttings during the autumn also began at around 40 days. Only clone AI 33 presented mini-cuttings with roots in the first evaluation. This clone, although showing a rapid increase in rooting up to 50 days, showed again the lowest rooting rate among the clones $\left(\varphi_{2}\right.$ $=68.982)$. As in spring and summer, clone Al40 showed the most rapid stabilization in the rooting process during
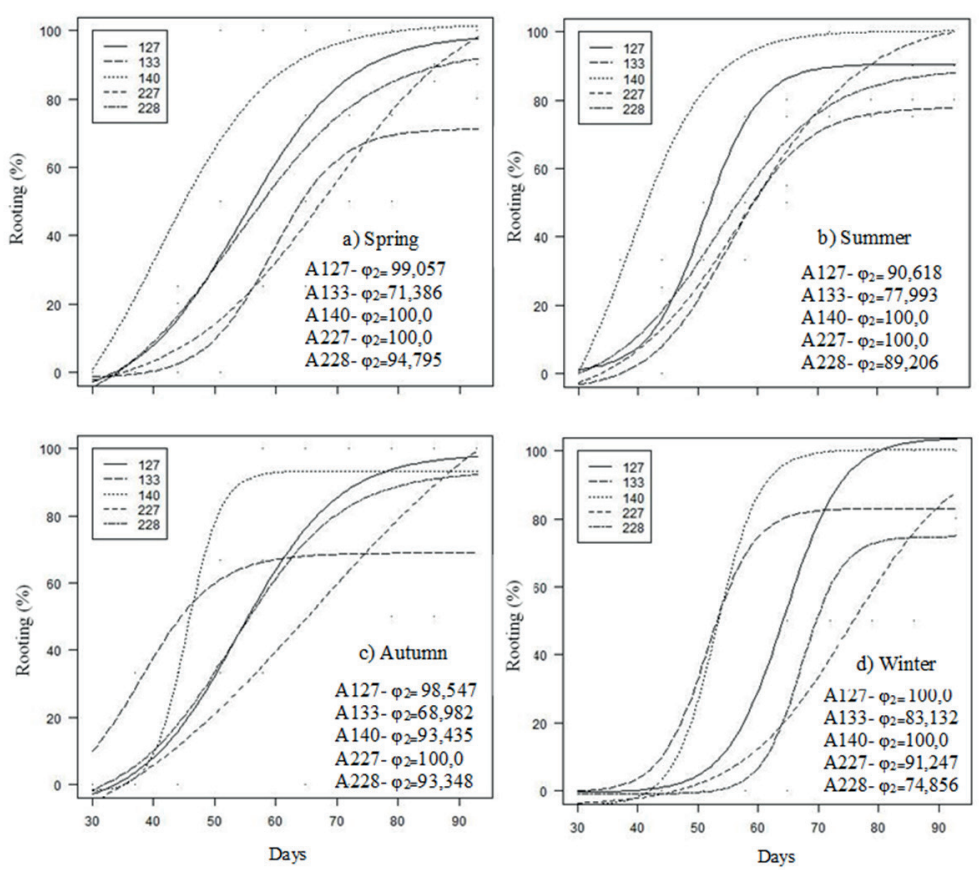

FIGURE 2 Roots of mini-cuttings of the clones of Sequoia sempervirens in function of time in mini-tunnel in the four seasons of the year. The coefficient $\varphi_{2}$ expresses the maximum rotation potential. autumn (close to 55 days). However, it did not reach $100 \%$ rooting. The only clone that showed maximum rooting during the autumn was A227. In winter, the coldest season of the year, the rooting began late in relation to the other seasons. For three clones the rooting began in almost 60 days and in two of them at around 50 days. Although rooting occurs later, all clones presented rates higher than $75 \%$, with two clones (AI40 and AI27) with $100 \%$.

For root formation in mini-cuttings during spring (Figure $3 \mathrm{a}$ ) there was a similarity among the clones. Root formation was progressive over the course of the time, with a tendency to stabilize after 80 days, obtaining on average between 8 and 12 roots per mini-cutting. In the summer, it was also possible to observe a linear behavior, except for clone A227 that stabilized at 60 days with approximately 6 roots (Figure $3 \mathrm{~b}$ ).

The highest variations for root formation among the clones were observed in the colder seasons (Figure $3 c$ and $3 d)$. The behavior of the clones was similar in both seasons, with a higher root formation after 70 days. At the final evaluation, there was a significant variation among the clones, with average of 3 roots for clone AI 33 and $\mathrm{I} 3$ for clone Al 40 .

Considering the statistical analysis of the variables at the end of the evaluation (93 days), it was possible to observe differences between the seasons for survival, rooting and the number of roots. In relation to the clones, there was a significant difference for callus formation (\%), rooting (\%) and the number of roots (Table I). 

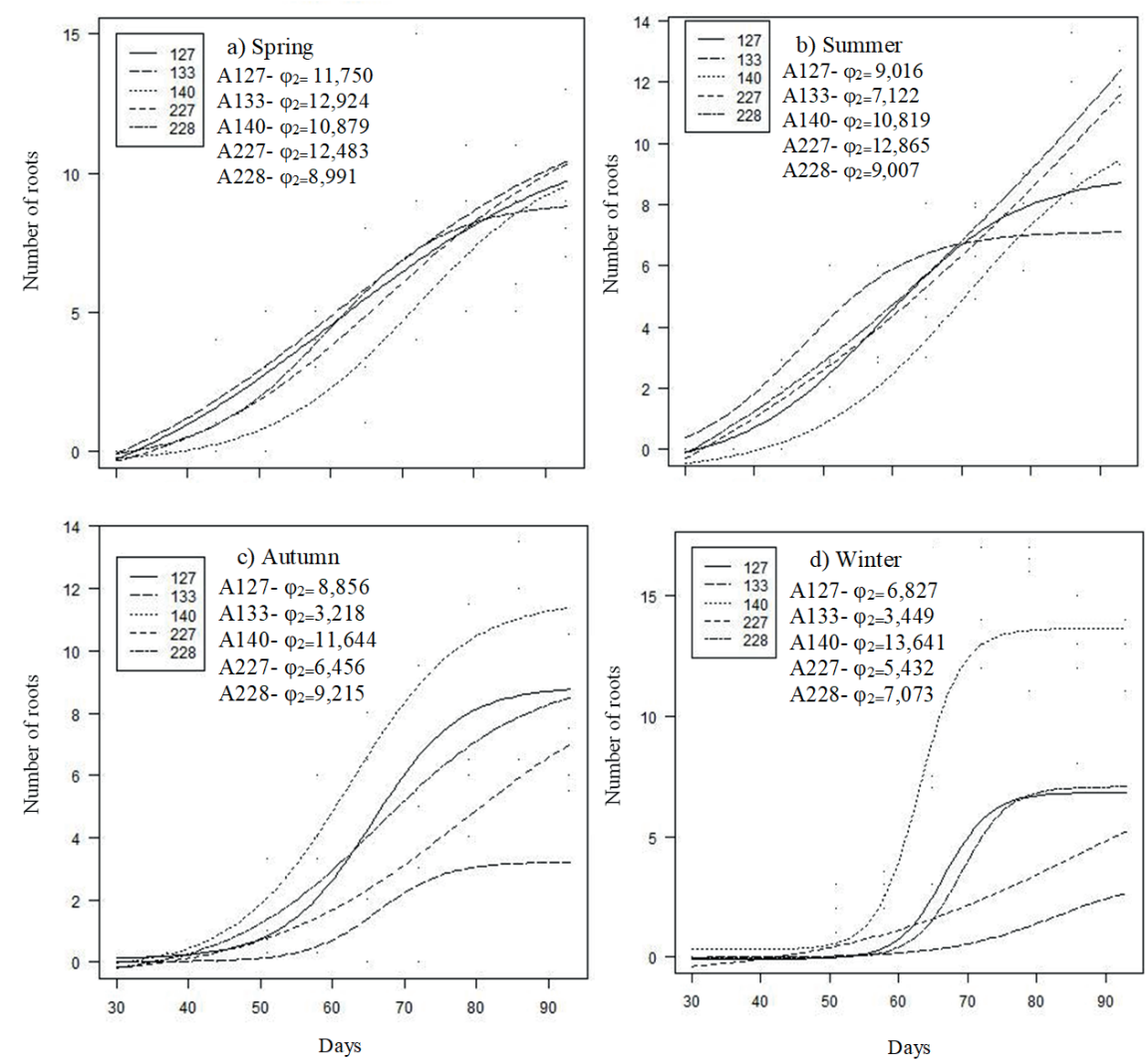

FIGURE 3 Number of roots in mini-cuttings of the clones of Sequoia sempervirens in function of time in mini-tunnel in the four seasons of the year. The coefficient $\varphi_{2}$ expresses the maximum value of training per roots.

TABLE I Formation of callus (\%), roots (\%) and the number of roots per mini-cutting of the clones of Sequoia sempervirens in different seasons of the year, 93 days after planting.

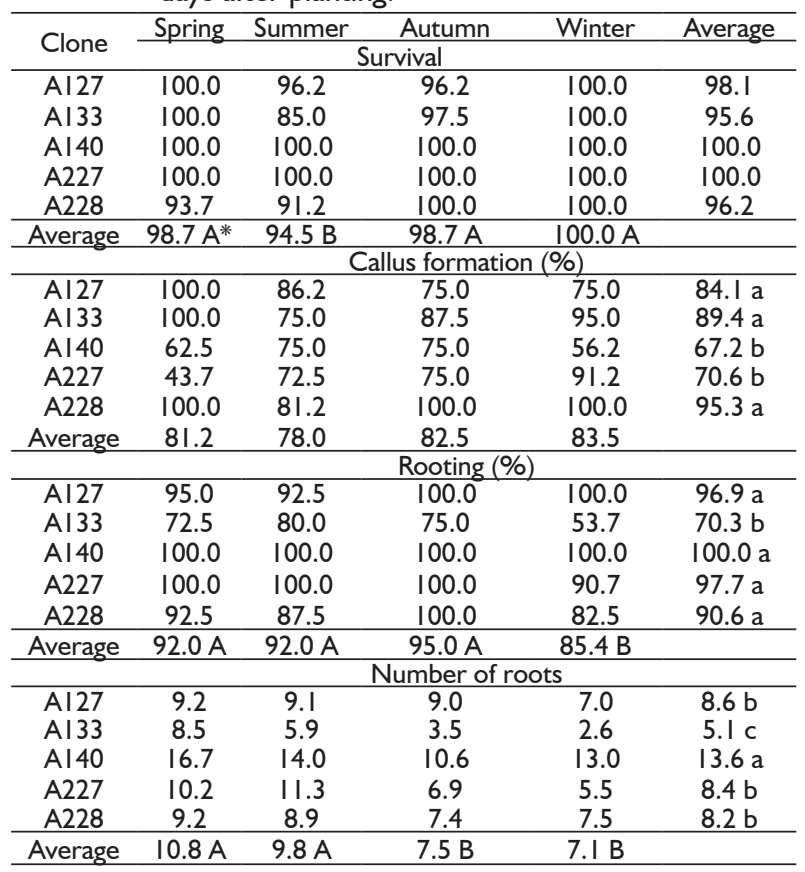

* Average followed by equal letters, upper case and lower case letters; do not differ by Scott-Knott test at $5 \%$ probability.

\section{DISCUSSION}

In an attempt to establish efficient cloning process of a species not cultivated in Brazil, but which presents a lot of potentials, the development of techniques for the vegetative propagation is required. Even on a worldwide scale, there is no efficient methodology for sequoia cloning, specially related to the effect of the genotype. Mini-cutting has been the clonal technique most commonly used in commercial species for many years. It presents advantages in species propagation, such as an increase in quality of systematization process, control of nutrition, production practices throughout the year and other details that make this technology more used.

The high survival of the sequoia mini-cuttings placed in mini-tunnel environment installed under shade proves the potential in the production of clonal plants in this type of environment for all seasons. Even during summer and winter, seasons considered more problematic in the region due to extreme temperatures, the results obtained in this study were excellent. Survival values for sequoia (>95\%) are higher than those of Eucalyptus, the main forest species planted in Brazil, as well as the production of plants by cloning using 
mini-cutting. Studies developed for Eucalyptus under greenhouse conditions generally showed survival rates close to $90 \%$ (Brondani et al., 2014).

It is known that climatic factors have a fundamental and direct influence on the rhizogenic process, as well as on the survival of mini-cuttings. Several studies evaluating the influence of seasonality on the rooting of mini-cuttings proved this hypothesis (Ferreira et al., 20 I0; Pires et al., 20I3). In this sense, the maintenance environment of mini-cuttings used in this study contributed greatly to the high rates of adventitious rooting obtained in all seasons of the year.

The rooting obtained during the spring season, period of greatest increase in rooting (60 and 80 days), is also the period of temperature rise in the study region. According to the data of the average temperature of the mini-tunnel (Figure I), the months of October and November recorded averages of approximately $21^{\circ} \mathrm{C}$, the suitable temperature for the rooting of cuttings/ mini-cutting of conifer species (Ragonezi et al., 2010). According to the same authors, the majority of works with conifer rooting achieve better results with higher temperatures during the day $\left(25-27^{\circ} \mathrm{C}\right)$ and lower during the night $\left(15-18^{\circ} \mathrm{C}\right)$. In general, these temperatures coincide with those obtained in the mini-tunnel. The location of the mini-tunnel under shade house allows a good thermal control, with temperatures not very high during the day nor low during the night (characteristic of the region). Good rooting results with the shade house were also obtained in Corymbia citriodora, Eucalyptus urophylla and Eucalyptus benthamii (Brondani et al., 2018).

The appropriate rooting average during spring were probably obtained because in this season the period of active growth in the plants restart. In addition, the reserve material is available, allowing the development of branches and roots (Hartmann et al., 20l I). Dutra et al. (2002) in a study with Prunus persica propagation, obtained the highest rooting in the spring and summer months when they found low levels of tryptophan in the cuttings. According to these authors, the amino acid may have been converted to indole-acetic acid (AIA) and used for development by plants.

In general, the percentage of rooting and number of roots obtained in the summer showed similarities compared to spring. The fastest onset (Figure 2b) of rooting (relative to spring) is related to the increase in temperature in the months of December and January, with averages close to $25{ }^{\circ} \mathrm{C}$ (Figure I). The temperature can influence the rooting process, acting mainly on nutrient absorption and metabolism, especially in subtropical climates. The cell division was favored by the increase of temperature and, consequently, thus it helps the roots formation (Souza et al., 2013). The temperature also plays a hormonal role. The highest rate of auxin synthesis occurs in the hotter seasons and the temperature has a direct effect on plant metabolism in higher chemical reactions (Wit et al., 2014). At the end of the evaluation, it was possible to observe that rooting in summer was similar values to spring, with all clones presenting rooting higher than $80 \%$.

In autumn rooting began at around 40 days, with a high potential between 50 and 70 days, tending to stabilize the curve after this period. During this period all clones, except for $\mathrm{Al} 33$, showed a $100 \%$ rooting rate at 93 days (Table I). When observing Figure 2c, there appears to be a difference between all clones, however, this is due to the adjustment of the original logistic function. Although a high percentage of rooting was observed, there was a reduction in relation to the number of roots. This result is possibly related to temperature. The beginning of the root differentiation occurred while the temperatures were still higher, around $18-20{ }^{\circ} \mathrm{C}$. The emergence of new roots, which usually occurs after 60 days of planting, occurred at the end of the autumn season when average temperatures were around $15^{\circ} \mathrm{C}$.

Ragonezi et al. (2010) studing conifers, indicated that in the hottest seasons the maturing plants were in a period of intense vegetative growth and for that reason mini-cutting collected at that moment is often more herbaceous, with high cambium activity and production of auxins, carbohydrates, and cofactors of rooting, as nitrogenous substances and phenolic compounds, attributing to these factors the highest percentage of rooting obtained. The best rooting result between spring and autumn is also related to higher solar radiation in this period. Cuttings submitted to high light intensity showed a higher rooting percentage than those submitted to low light intensity (lacona and Muleo, 2010). In spite of this, the effects of the quantity and quality of light corresponding to each season of the year are variable among conifers species, being able to suppress or increase the percentage of rooting (Fragoso et al., 20I5).

The mini-cutting in process of rooting during winter presented the lowest average in relation to the other seasons, resulting in 7 to $10 \%$ less rooting when considered the averages of all clones. The main difference in the rooting process during the winter was in the period of appearance of the first roots, only after 50 days. However, after this period there was a rapid root formation, and between 60 and 70 days occurred the highest percentage of rooting. The significant increase in 
the formation of new roots also occurred after 70 days. In relation to the other seasons, the number of roots at the end of the evaluation was lower, except for the clone Al40, that showed similarity throughout the year.

Lower results for rooting during the winter were also found in other propagation studies by cutting or mini-cutting, even when applied growth regulators (Alcantara et al., 2008). This result may be associated with the fact that, at that time, woody plants are in a state of dormancy to protect their meristem from low temperatures, with reduction of activities in the young tissues of the secondary phloem, vascular rays and cambium and, in contrast, with increased concentrations of phenolic compounds and inhibitors, temporarily interrupting their growth (Olsen, 2010).

In addition, it was possible to had greater lignification of the mini-stumps branches due to the increase of peroxidase enzymes, which can also be responsible for auxin degradation (Tehranifar et al., 2014). This hormonal reduction is often observed in temperate perennial species, such as sequoia tree, in which auxin levels are low in winter (Rasmussen et al., 2009) and are therefore one of the factors that contribute to the lowest percentages of rooting (Fragoso et al., 2015).

In the present study, it is possible to notice a significant difference between the clones tested for the mini-cutting technique, with an effect in practically all variables evaluated. In rooting, for example, clone Al 33 presented a mean of $70 \%$ in all seasons and with 5 roots, while the others had rate values higher than $90 \%$ and at least 8 roots per mini-cutting. This difference, possibly obtained by the genetic character, is probably a consequence of the high genetic variability that the sequoia presents due to unusual hexaploid genome (six copies of the chromatids) (Ahuja, 2009). In addition to the diversity of species, the process of rooting is genotype dependent. Even parental clones can promote different indexes and rooting processes (Mokotedi et al., 2000). It is known that there is variation in the levels of endogenous auxins and rooting cofactors as a function of the clones (Osterc et al., 2009).

The variation in rooting capacity is similar to that found by Pereira et al. (2017) in Sequoia sempervirens and other woody species such as Chamaecyparis nootkatensis (Krakowski et al., 2005), Taxus globosa (Muñoz-Gutiérrez et al., 2009) and many others. The clonal variation in rooting capacity is an attribute in many studies on genetic effects (Owais, 2010) and "C" clonal effect; the latter defined as unique physiological or morphological characteristics for the branch (stake) reflecting in its growth environment.
Considering that, the sequoia trees from which the material recovered by ringing were obtained in the same place and age, it is possible to determine that the difference in rooting capacity is related to the genetic effect. It should also be considered that there is no effect of topophysis, cypophysis, environments and materials used. One of the factors that may indicate the inferiority of clone AI 33 is a lower growth in the experimental area of vegetative rescue (São Francisco de Paula-RS). This clone had a wood volume lower than $\mathrm{I} \mathrm{m}^{3}$, while the others (from this study) reached a volume higher than $3 \mathrm{~m}^{3}$.

Adventitious rooting is probably a feature with a significant genetic component. Thus, early selection based on the early years of production or even plants in the nursery contributes to the reduction of selection time in breeding programs. The early selection of genotypes for adventitious rooting within forest breeding programs can greatly contribute to further reduced selection time since it would circumvent the problem of choosing recalcitrant genetic material for vegetative propagation (Oliveira et al., 20I5).

However, for sequoia tree, which is in adaptation and growth tests are being conducted outside of natural occurrence, it is important to verify the rooting ability, but without eliminating clones with low indexes before the establishment of clonal tests with silviculture evaluations. The next step of this study will be to evaluate clonal tests in different regions, aiming studies of adaptation, growth and wood characteristics of the species.

\section{CONCLUSION}

The rooting process of sequoia mini-cuttings presents clonal influence. The lowest rooting of sequoia mini-cuttings is obtained during winter (85\%). In other seasons, rates of over $90 \%$ are reached.

The rooting of mini-cuttings occurs between 50 and 70 days after the planting. It is indicated the maintenance for 90 days of mini-cuttings in the rooting environment.

\section{ACKNOWLEDGMENTS}

The authors would like to thank Coordenação de Aperfeiçoamento de Pessoal de Nível Superior (CAPES) and Conselho Nacional de Desenvolvimento Científico e Tecnológico (CNPq) for the scholarship awarded.

\section{REFERENCES}

AHUJA, M. R. Genetic constitution and diversity in four narrow endemic redwoods from the family Cupressaceae. Euphytica, v. I65, n. I, p. 5-19, 2009. 
ALCANTARA, G. B.; RIBAS, L. L. F.; HIGA, A. R.; ZUFFELLATORIBAS, K. C. Efeitos do ácido indolbutírico (AIB) e da coleta de brotações em diferentes estações do ano no enraizamento de miniestacas de Pinus taeda L. Scientia Forestalis, v.36, n.78, p.I5I-I56, 2008.

BOURGKARD, F; FAVRE, J. M. L'embryogenèse somatique chez Sequoia sempervirens possibilités et limites actuelles. Annales de Recherches Sylvicoles, p. 83-95, 1989.

BRONDANI, G. E.; BACCARIN, F. J. B.; BERGONCI, T.; GONÇALVES, A.N.; ALMEIDA, M. Miniestaquia de Eucalyptus benthamii: efeito do genótipo, AIB, zinco, boro e coletas de brotações. Cerne, v. 20, n. I, p. I47- I56. 20 I4.

BRONDANI, G. E.; OLIVEIRA, L. S.; KONZEN, E. R.; SILVA, A. L. L.; COSTA, J. L. Mini-incubators improve the adventitious rooting performance of Corymbia and Eucalyptus microcuttings according to the environment in which they are conditioned. Annals of the Brazilian Academy of Science, v. 90, n. 2 Suppl. I, p. 2409-2423, 2018.

DONNET, A. Le Sequoia sempervirens: programme de recherche et de développement mené en France par l'afocel. Mém 3 e année, École Nationale des Ingénieurs des Travaux des Eaux et Forêts et Afocel, Région NordOuest, 104 p. 1984.

DUTRA, L. F.; KERSTEN, E.; FACHINELLO, J. F. Época de coleta, ácido indolbutírico e triptofano no enraizamento de estacas de pessegueiro. Scientia Agricola, v. 59, n.2, p.327-333, 2002.

FERREIRA, B. G. A.; ZUFFELLATO-RIBAS, K. C.; WENDLING, I.; KOEHLER, H.S.; NOGUEIRA, A. C. Miniestaquia de Sapium glandulatum (Vell.) Pax com o uso de ácido indol butírico e ácido naftaleno acético. Ciência Florestal, v.20, n.I, p.19-3I. 2010.

FRAGOSO, R. O.; ZUFFELLATO-RIBAS, K. C.; MACANHÃO, G.; STUEPP, C. A.; KOEHLER, H. S. Propagação vegetativa de Juniperus chinensis. Comunicata Scientiae, v.6, n.3, p.307-316, 2015.

HARTMANN, H. T.; KESTER, D. E.; DAVIES JUNIOR, F. T.; GENEVE, R. L. Plant propagation: principles and practices. 8th ed. New Jersey: Prentice-Hall, 915 p. 201 I.

IACONA, C.; MULEO, R. Light quality affects in vitro adventitious rooting and ex vitro performance of cherry rootstock Colt. Scientia Horticulturae, v.125, n.I, p.630-636, 2010.

KRAKOWSKI, J.; BENOWICZ, A.; RUSSELL, J. H.; ELKASSABY, Y. A. Effects of serial propagation, donor age, and genotype on Chamaecyparis nootkatensis physiology and growth traits. Canadian Journal of Forest Research, v.35, n.3, p. 623-632. 2005.

LING, W. X.; ZHONG, Z. Seasonal variation in rooting of the cuttings from Tetraploid Locust in relation to nutrients and endogenous plant hormones of the shoot. Turkish Journal of Agriculture and Forestry, v.36, n. I, p. 257-266, 2012.
MOKOTEDI, M. E. O.; WATT, M. P.; PAMMENTER, N. W. In vitro rooting and subsequent survival of two clones of cold-tolerant Eucalyptus grandis X Eucalyptus nitens Hybrid. Hortscience, v.35, n.6, p. I I63-I I65, 2000.

MUÑOZ-GUTIÉRREZ, L.; VARGAS-HERNÁNDEZ, J.; LÓPEZ-UPTON, J.; SOTO-HERNÁNDEZ, M. Effect of cutting age and substrate temperature on rooting of Taxus globose. New Forests, v.38, n.2, p. 187-196, 2009.

OLIVEIRA, L. S.; XAVIER, A.; DIAS, P. C.; CORREIA, A. C. G.; BORGES, S. R., TAKAHASHI, E. K., PAIVA, H. N. Enraizamento de miniestacas e microestacas de clones de Eucalyptus urophylla $\times$ E. globulus. Scientia Forestalis, v.40, n.96, p.507-516, 2012.

OLIVEIRA, L. S.; DIAS, P. C.; ALMEIDA, M. Avaliação genética do enraizamento de miniestacas de uma procedência de Eucalyptus cloeziana. Pesquisa Florestal Brasileira, v.35, n.84, p.39I-397, 2015.

OLSEN, J. E. Light and temperature sensing and signaling in induction of bud dormancy in woody plants. Plant Molecular Biology, v.73, n. I, p.37-47, 2010.

OSTERC, G.; ŠTEFANČIČ M.; ŠTAMPAR, M. Juvenile stockplant material enhances root development through higher endogenous auxin level. Acta Physiologiae Plantarum, v.3I, n.5, p.899 - 903, 2009.

OWAIS, S. J. Rooting response of five pomegranate varieties to indole butyric acid concentration and cuttings age. Pakistan Journal of Biological Sciences, v. 13, n.2, p.5I8, 2010.

PEREIRA, M. O.; ÂNGELO, A. C.; NAVROSKI, M. C.; DOBNER JÚNIOR, M.; OLIVEIRA, L. M. Vegetative rescue and rooting of cuttings of different stock plants of Sequoia sempervirens. Cerne, v.23, n.4, p.435-444, 2017.

PIRES, P. P.; WENDLING, I.; BRONDANI, G. Ácido indolbutírico e ortotropismo na miniestaquia de Araucaria angustifolia. Revista Árvore, v.37, n.3, p.393-399, 2013.

RAGONEZI, K.; KLIMASZEWSKA, K.; CASTRO, M. R.; LIMA, M.; OLIVEIRA, P.; ZAVATTIERI, M. A. Adventitious rooting of conifers: influence of physical and chemical factors. Trees, v.24, n. I, p.975-992, 2010.

RASMUSSEN, A.; SMITH, T. E.; HUNT, M. A. Cellular stages of root formation, root system quality and survival of Pinus elliottii var. elliottii $x$ P. caribaea var. hondurensis cuttings in different temperature environments. New Forests, v.38, n.3, p.285-294, 2009.

SOUZA, C. C.; XAVIER, A.; LEITE, F. P.; SANTANA, R. C.; LEITE, H. C. Padrões de miniestacas e sazonalidade na produção de mudas clonais de Eucalyptus grandis Hill X E. urophylla S. T. Black. Revista Árvore, v.37, n.I, p.67-77, 2013. 
TEHRANIFAR, A.; TABAR, S. M.; SELAHVARZI, Y.; BALANDARY, A.; KHARRAZI, M. Biochemical changes in barberries during adventitious root formation: the role of indole-3-butyric acid and hydrogen peroxide. Spanish Journal of Agricultural Research, v.12, n.2, p.477-485, 2014.

TOSTA, M. S.; OLIVEIRA, C.V. F.; FREITAS, R. M. O.; PORTO, V. C. N.; NOGUEIRA, N. W.; TOSTA, P. A. F. Ácido indolbutírico na propagação vegetativa de cajaraneira (Spondias sp.). Semina: Ciências Agrárias, v.33, n.l, p.2727-2740, 2012.
TRUEMAN, S. J.; MCMAHON, T. V.; BRISTOW, M. Production of cuttings in response to stock plant temperature in the subtropical eucalypts, Corymbia citriodora and Eucalyptus dunnii. New Forests, v.44, n.2, p.265-279, 2013.

TOMBESI, S.; PALLIOTTI, A.; PONI, S., FARINELLI, D. Influence of light and shoot development stage on leaf photosynthesis and carbohydrate status during the adventitious root formation in cuttings of Corylus avellane L. Frontiers in Plant Science, v.6, n.973, p.I-I3, 20 I5.

WIT, M.; LORRAIN, S.; FANKHAUSER, C. Auxin-mediated plant architectural changes in response to shade and high temperature. Physiological plantarum, v.15I, n. I, p.I3-24, 2014. 